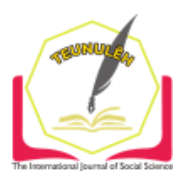

Jurnal Ilmiah Teunuleh

The International Journal of Social Sciences

Vol. 2, Issue. 2, June 2021

E-ISSN: $2746-4393$

\title{
OUTDOOR LEARNING-BASED THEMATIC LEARNING
}

\author{
Yulia Karlina ${ }^{1}$ \\ Universitas Lampung St. Prof. Dr. Sumantri Brojonegoro No 1 Bandar Lampung, \\ Indonesia \\ yuliakarlina90@gmail.com \\ Rochmiyati \\ rochmiyatiazwardi@yahoo.co.id \\ Dwi Yulianti ${ }^{3}$ \\ shafira_shodiq@yahoo.com
}

\begin{abstract}
This research is a research on developing a test instrument for higher-order thinking skills based on outdoor learning for fifth grade elementary school students. This study aims to 1) develop a test instrument for higher order thinking skills based on outdoor learning in elementary schools; 2) validate the test instrument through expert validation and empirical validity. Expert validation is carried out by consulting the product development design with expert lecturers. Empirical validity was carried out using the product moment correlation formula, while the determination of reliability used the Cronbach Alpha formula. The research method uses Design Based Research. The development of this model is carried out in stages 1) identification and problem analysis by researchers and practitioners collaboratively 2) developing solutions based on theoretical benchmarks, existing design principles and technological innovations 3) carrying out an iterative process to test and improve practical solutions 4) reflection to produce design principles and improve implementation of practical solutions. The results of the study are 1) 22 items of higher order thinking skills; 2) validation by experts states that this assessment instrument is suitable for use as an assessment tool, while in empirical validation it is stated that the overall results of the test using the product moment formula of the items have been declared valid. Determination of reliability using Cronbach's alpha formula has a reliability value of 0.935 which is categorized as high reliable. Overall, in this development research, this higher-order thinking ability assessment instrument is valid and reliable as a form of assessment.
\end{abstract}

Keywords: Thematic Learning, Outdoor Learning, Grade V Elementary School Students 


\section{A. Introduction}

Education in the Industrial Revolution 4.0 era is directed at developing 21st century competencies. according to (Sutanto, 2019)one of the components in 21st century competence is thinking competence which includes critical thinking, creative thinking and problem solving abilities. 21st century education prepares young people who are creative, flexible, able to think critically, can make the right decisions, and are skilled in problem solving. (Ridwan AS, 2019, p. 52). Higher order thinking skills are usually carried out in the learning process in the classroom. Like contextual learning, students are able to build knowledge through their personal experiences. Contextual learning at the elementary school level can be given during thematic learning (Subadar, 2017, p. 83).

The presence of the curriculum is closely related to educational goals, as stated in Law no. 20 of 2003 which contains National Goals and Madrasah or Institutional Goals relating to the terms Core Competencies, Basic Competencies, and Graduate Competency Standards. Education plays a very important role in developing the economy and also the development of the country. The determinant of a country's success in facing global economic competition today depends on the skills, knowledge and competencies possessed by the community (Kleman, 2021, p. 835). The 2013 curriculum is designed with improvements to content standards in reducing irrelevant material as well as deepening and expanding relevant material so as to improve critical and analytical thinking. Curriculum 2013 in which there is a demand that it is necessary to develop higher order thinking skills or HOTS of students starting from elementary school (Andrean, 2020, p. 64). The HOTS foundation emphasizes analytical thinking skills and the efforts of educators in training students' higher-order thinking skills by developing elements in learning that do not only refer to memory or memorization but also to analysis and solving a problem. (Fazriani, 2019, p. 126).

Students are expected to be able to predict, estimate, and design as required and a requirement of the 2013 Curriculum. Along with this statement, the field of Higher Order Thinking Skills or what can be called HOTS includes the process of analysis (C4), evaluation (C5), and create (C6). The skills can be trained to students by way of implementing the 4Cs-oriented test questions by using a higher order thinking skills (HOTS)-based assessment instrument (Okayana, 2019, p. 135). These competencies will be needed in the 21st century. Creative thinking is the result of developing oneself in the form of mental activities to produce new things (Setyawan, 2020, p. 513). All subjects in 
science and technology are carried out through school exams or madrasa exams to determine whether these students graduate from the relevant educational institution.

Students must get a score equal to or greater than the minimum value set by the BSNP to be able to take the school or madrasa exam. According to Kesuma (Kusuma, 2017 , p. 1) that This result shows that most of Indonesian students still have low ability, if it is seen from cognitive aspect (knowing, applying, reasoning). Based on the explanation above, it is explained that if it is connected in the world of education, the purpose of the assessment in learning is to find out to what extent and to what extent the learning material has been received by students so that it can be seen the difference between students who have achieved and those who have not achieved the learning objectives. Martínez and Lozano (Gonzales, 2020, p. 1) reported that when applying soft music in the classroom in the background, students who had more points in their musical intelligence saw a strong and positive impact on academic achievement. According to the Regulation of the Minister of Education and Culture Number 23 of 2016, assessment is a way to collect and process information that has been obtained to measure the achievement of a student's learning outcomes. There are three abilities that are assessed to determine learning outcomes, namely knowledge, attitudes and skills.

The assessment given to students is expected to be able to improve higher-order thinking skills. Critical thinking, metacognitive, reflective, logical and creative thinking skills are higher order thinking skills. Students in elementary schools must begin to be trained in their ability to think at higher levels, but also remain in their portions. In other words, students are trained according to their development and age because in fact students in elementary schools have great curiosity and need more attention. Creative and critical thinking is a characteristic of higher order thinking skills. (Hidayati, 2017, p. 145) Based on the pre-research that the author did, it is known that the application of the instrument of higher order thinking ability of participants can be seen if an educator can provide HOTS-based assessment questions.

\section{B. Method}

The research method used is the Design Base Research method. Definition of Design Based Research (DBR) according to Plomp (2007, p. 2) design research is a systematic study of designing, developing and evaluating educational interventions (such as programs, strategies and learning materials, products and systems) with the aim of solving complex problems in problems education, which aims to advance our knowledge 
of the characteristics of these interventions and the processes for designing and developing education. From this explanation, it can be concluded that Design Based Research aims to develop learning that focuses on solutions to existing problems. Therefore,

Research Steps Design Based Research Activities carried out at the stage of identifying and analyzing problems by researchers and practitioners collaboratively are conducting a preliminary study to four elementary schools using the 2013 curriculum in Bandar Lampung City. Interviews and documentation studies are data collection techniques carried out by researchers to obtain information related to the use of learning designs in elementary schools. Based on this, researchers began to develop solutions based on theoretical benchmarks, existing design principles and technological innovations.

The development carried out by the researchers was in the form of a thematic learning design based on outdoor learning on the sub-themes of Temperature and Heat for students of class V Elementary School with two lessons. Then in the third stage, the researcher carried out an iterative process to test and improve the solution practically. Testing is carried out internally and externally. For internal testing, two expert lecturers are competent in their fields. Meanwhile, the external test was carried out on the research subjects, namely teachers and students of class V Elementary School. The last stage is reflection to produce design principles and improve the implementation of practical solutions, at this stage researchers reflect on the learning designs that have been developed.

Weaknesses found during the trial process will be used as a solution for improvement until a product that is truly suitable for use is produced. The research was conducted in two elementary schools, namely SDN 1 Sepang Jaya, Kedaton District, Bandar Lampung City. The subjects of the research data sources were teachers and students of class $V$. To obtain research data, researchers used data collection techniques with questionnaires and observations of videos of the learning process. Data analysis was carried out using the Milles and Huberman model (Sugiyono, 2013, p. 246) which consists of three stages of activity, namely data reduction (data reduction), data display (data presentation), and conclusion drawing/verification (drawing conclusions/verification). Data analysis was carried out by analyzing the results of questionnaires and observing videos of learning activities. The results of the analysis are presented in the form of descriptive text descriptions and in tabular form. After the data is presented, the 
researcher draws conclusions from the results of research and development of thematic learning designs based on outdoor learning in elementary schools.

\section{Results and Discussion}

\section{Perform problem identification and analysis}

At this stage the researcher identified and analyzed problems regarding the focus of research by conducting interviews with fifth grade teachers and studying documentation of the questions that had been made by the teacher. The results of interviews and documentation studies were then analyzed to find out how the test questions currently developed in elementary schools are linked to the thinking skills developed by teachers in making test questions.

\section{Developing Solutions}

After the researchers identified the problem in the development of test questions, namely the lack of development of HOTS questions in elementary schools, the researchers conducted a theoretical study of higher-order thinking and the curriculum to develop a HOTS-based test item design. In this stage there are several stages carried out by researchers, including:

\section{a. Analysis of learning materials}

After analyzing the students, the researcher chose to develop questions in class $\mathrm{V}$. The researcher began to review the curriculum to determine which material to choose. The theme chosen is the theme of heat and its displacement sub-themes of temperature and heat. With Indonesian PPKn, IPA, and SBK subjects. With the outdoor learning method to create direct and meaningful learning. Spandy and Marshall (Eaton, 1998, p. 40)mentions that instruction in outdoor learning activities will focus on higher-order thinking, namely on the ability to analyze, evaluate and create and be competent for all students.

\section{b. Indicator Analysis}

After that, the researcher analyzed the learning indicators carried out in outdoor learning. The learning indicators were used as questions indicators.

\section{c. Analysis of learning objectives}

After analyzing the learning indicators, the writer analyzes the learning objectives. This is done to determine the conditions used in achieving learning indicators. (Hamid, 2013, p. 4) is a learning goal containing the mastery of operational competencies and is targeted to be achieved in learning. 
Yulia Karlina, Rochmiyati, Dwi Yulianti

\section{d. Preparation of HOTS Questions}

\section{1) Grid Arrangement}

Furthermore, the researchers arranged a grid of questions as follows:

Table1

\begin{tabular}{|c|c|c|c|c|c|}
\hline Subjects & $\begin{array}{c}\text { Basic } \\
\text { competencies }\end{array}$ & $\begin{array}{c}\text { Indicator } \\
\text { Competence }\end{array}$ & $\begin{array}{l}\text { Question } \\
\text { Indicator }\end{array}$ & $\begin{array}{l}\text { Question } \\
\text { Number }\end{array}$ & $\begin{array}{c}\text { Cognitive } \\
\text { Aspect }\end{array}$ \\
\hline Indonesian & $\begin{array}{l}3.3 . \\
\text { Summarizing } \\
\text { explanatory } \\
\text { text } \\
\text { (explanation) } \\
\text { from } \\
\text { print/electronic } \\
\text { media }\end{array}$ & $\begin{array}{l}\text { Make a text } \\
\text { narrative } \\
\text { summary of } \\
\text { the video or } \\
\text { image } \\
\text { presented }\end{array}$ & $\begin{array}{l}\text { Making } \\
\text { conclusions } \\
\text { from } \\
\text { reading } \\
\text { texts from } \\
\text { print media }\end{array}$ & $\begin{array}{c}5 \\
\text { (essays) }\end{array}$ & C6 \\
\hline
\end{tabular}

\section{2) Rubric}

The next stage is the preparation of the rubric for the essay questions as follows:

Pay attention to the following text!

On a very hot day, the windows of the house can shatter. The breaking of the glass occurs because the glass expands. If there is not enough space in the window frame to accommodate this expansion, the frame will resist the expansion of the glass. As a result, the glass can break. To overcome this problem, the size of the window glass frame is designed to be slightly larger than the size of the glass at normal temperatures.

Make a conclusion from the reading text!

Answer key:

Window glass can break due to exposure to sunlight due to the expansion process in the glass because the glass frame is not enough.

Rubik's Cube:

\begin{tabular}{|l|l|}
\hline Maximum Value 3 & Criteria \\
\hline 3 & $\begin{array}{l}\text { Students fill in the correct answer to } \\
\text { the question along with the reason }\end{array}$ \\
\hline 2 & $\begin{array}{l}\text { Students fill in correctly without } \\
\text { being accompanied by reasons }\end{array}$ \\
\hline 1 & Students fill in incorrectly \\
\hline
\end{tabular}


Outdoor Learning-Based Thematic Learning

\section{3) HOTS-based test questions stage 1}

Examples of HOTS-based test questions stage 1 are:

- Roni's father owns a company. The company turned out to be dumping industrial waste into the sea. As a result, many fish die because the sea water is polluted by the waste. What do you think should be done to overcome this pollution?

a. Treating industrial waste before dumping it into the sea

b. Stem the flow of waste from industry

c. Keeping fish that are resistant to industrial waste

Because a good question is a question that measures what you want to measure. As explained in the previous chapter. The author conducted expert validation with the help of two experts. In order to find out how the quality of the questions before the trial 1 .

\section{e. Revision I}

There are no questions that have changed but the changes in the writing of the questions are due to make it easier for students to answer questions. Changes also occur in the assessment rubric because essay questions must be assessed more objectively with the help of a good rubric.

\section{f. Revision II}

The questions underwent revision II based on considerations of validity, reliability, discriminatory power, level of difficulty, and distractors.

\section{g. Trial I}

The first trial was conducted in Class VA of SDN 1 Sepang Jaya in the even semester of the 2020/2021 school year, on April 6 and 8, 2021 for two days. Thematic learning followed by VA class students with 35 students. The implementation of the first trial was assisted by a team of learning tools, namely learning design, worksheets, learning media, attitude assessment, performance assessment and learning videos in outdoor learning.

From the analysis of multiple choice questions, it shows that there are 5 valid questions, namely numbers 1,2,3,6, and 10 and 8 invalid questions, namely numbers 2 , 6 and 10. Furthermore, for essays, it shows that there are 8 valid questions. After that, the device was analyzed again using the SPSS program, Microsoft excel, and manually using the product moment correlation formula.

From the validation data on multiple choice and essay questions, it shows that all questions are valid. Because the validity score exceeds the R-table value. From the data, 
the multiple-choice reliability value has a value of 0.757 , this indicates that the questions are reliable. And for essay questions, it has an alpha value of 0.717 , indicating that the questions are reliable because both of them exceed the R-table value of 0.444 .

\section{Revision III}

After the second trial, the questions were declared both in terms of validity and reliability. Then the question is declared feasible to use. Furthermore, in revision III, not many were revised, only on number 7 essay. Added an editorial on the question to make it clearer.

\section{Doing Reflection to Generate Design Principle}

In the next stage, the HOTS question product was successfully developed with several revisions from both experts and according to the results of the validity and reliability analysis.

\section{Conclusion}

Based on the results of research and development of HOTS-based test questions on the outdoor learning model in elementary schools with the theme of heat and its transfer and the sub-themes of temperature and heat, several conclusions were drawn.

1. In elementary school test questions have been developed to measure students' cognitive abilities. The test questions developed vary from multiple choice, short entry, essay, and others. In general, teachers have heard of blooming thinking skills, but in making questions, teachers often develop low-level thinking skills or LOTS (Lower-Order Thinking Skills). Because the teacher in making questions does not pay too much attention and focus on what thinking skills must be developed and possessed by students, but is more adapted to learning indicators which are then developed into questions indicators.

2. Researchers in developing at the design stage by referring to learning indicators that are used as indicators of questions, namely the development of the 2013 curriculum with the theme of heat and its transfer, sub-themes of temperature and heat. In outdoor learning, it integrates several subjects, namely Indonesian, Social Sciences, Science and SBK. The design is arranged in the form of a grid, an essay rubric. and numbers with 11 multiple choice and 11 essays or descriptions.

3. In the implementation of the HOTS questions, the next design was validated by two experts and underwent revision I. A total of 22 questions were tested to determine the quality of the questions. In the multiple-choice I trial there were 5 
Outdoor Learning-Based Thematic Learning

valid questions and 6 questions that were still not valid. While 8 valid essays and 3 questions are still not valid, with an R-table value of 0.444 . As for the reliability of multiple choice questions, the alpha value is 0.664 and the essay is 0.657 . Both have numbers above the R-table so that they can be declared reliable. Furthermore, the questions underwent revision II as many as 11 questions before the second trial was carried out. Trial II was carried out with improved results. The question gets a validity score above the R-table or 20 questions are declared valid. While reliability got an alpha value of 0.757 for multiple choice and 0.717 for essay. The questions get an alpha value above the R-table so that the questions can be declared reliable. The set of questions also underwent revision III on essay number 7 by adding pictures to the questions and changing the editorial to make it easier for students to answer questions.

4. The results were obtained in the form of a HOTS-based test set for outdoor learning in class $V$ with the theme of heat and its transfer and the sub-themes of temperature and heat. The test consists of 10 questions. 10 multiple choice questions and 10 essay questions developed are valid, reliable, and feasible to use.

\section{Bibliography}

Agustin, I. (2018). Pengembanagan Instrumen Penilaian Kinerja berbasis Outdoor Learning di SD. Jurnal IImiah Pendidikan Guru Sekolah dasar, 5,(1), 206-211.

Andrean, S. (2020). Developing Strategies and Evaluation Of Hots Based Learning On Thematic Learning In Elementary School. . International Journal on Islamic Educational Research (SKIJIER), 2(2).

Azizan, M. A. ( 2019). Pembelajaran Tematik SD/MI. Yogyakarta: Penerbit Samudra Biru.

Badrun, K. (2015). Pengembangan Instrument Pembelajaran di Sekolah Bertaraf Internasional. Yogyakarta: Fakultas Teknik Pascasarjana Universitas Negeri Yogyakarta.

Churches, A. (2009). Bloom's Digital Taxonomy. Journal: The Resource for Education Technology.

Dwi Isnaini Amin, D. s. (2018). Instrument Assesment Pemahanan Konseptual Berorientasi HOTS-Keterampilan Proses dan sikap Terhadap Sains padaBahan Kajian Hidrokarbon dan Minyak Bumi", , Vol 3 No 9. Jurnal Pendidikan, 3(9).

Eaton, D. (1998). Cognitive and Affective Learning In Outdoor Education. (Tesis). Department of Curriculum,. Toronto: Teaching and Learning Ontario Institute of Studies in Education of the University of Toronto. 
Fazriani, N. D. (2019). Pengaruh Pendekatan HOTS Terhadap Keterampilan Membaca Peserta Didik. Jurnal Stilistika, 12 (2).

Gonzales, I. M. (2020). Assessment of multiple intelligences in elementary school students in Mexico: An exploratory study. journal homepage: wWw.cell.com/heliyon., 6 . doi:doi.org/10.1016/j.heliyon.2020.e03777

Hamid, A. (2013). Implementasi Pendidikan Karakter Dalam Pembelajaran PKN pada Kelass Reguler danKelas SSI. Journal: Prodi Pendidikan Pancasila dan kewarganegaraan,.

Heong, y. (2011). The Level Marzano Higher Order Thinking Skills Among Technical Education Students. . Journal : International of Social Science and Humanity.

Herawati, R. (2014). Pengembangan Asesmen Hots pada Pembelajaran Berbasis Masalah Tema Bermain Dengan Benda-Benda Di Sekitar.

Herrington, d. (2007). Design Based Research and doctor alstudents: guidelines for preparing a dissertation proposal. ECU Publication Pre 2011. Edith Coan University: ECU Publication Pre 2011.

Hidayati, A. U. (2017). Melatih Keterampilan Berpikir Tingkat Tinggi Dalam Pembelajaran Matematika Pada Siswa SD. Jurnal Pendidikan Dan Pembelajaran Dasar, 4 (2).

Hosnan. (2014). Pendekatan Saintifik dan Kontekstual dalam Pembelajaran Abad 21 Kunci Sukses Implementasi Kurikulum 2013. Bogor: Ghalia Indonesia.

Irmawan, S. d. (2020). Development of instructional materials based on mobile learning media (MLM) and its benefits. . Journal of Physics: Conference Series 1842 (2021) 012023. doi:10.1088/1742-6596/1842/1/012023

Keleman, M. d. (2021, April). Assessment of Higher Order Thinking Skills Through Stem Integration Project-Based Learning for Elementary Level DOI: 10.47191/ijsshr/v4-i4-40. International Journal of Social Science And Human Research, 4(4). doi:10.47191/ijsshr/v4-i4-40

Kemendikbud. (2013). Panduan Teknis Pembelajaran Tematik Terpadu dengan Pendekatan Saintifik di Sekolah Dasar . Jakarta: Kemendikbud Direktorat Jenderal Pendidikan Dasar Direktorat Pembinaan Tahun 2013.

Krathwohl, A. a. (2001). A Taxonomy for Learning, Teaching and Assessing: A Revision of Bloom's Taxonomy of Educational Objectives. . New York: Addison Wesley Longman,Inc.

Kusuma, M. D. (2017). The Development of Higher Order Thinking Skill (Hots) Instrument Assessment In Physics Study. ) Volume 7, Issue 1 Ver. III (Jan. - Feb. IOSR Journal of Research \& Method in Education (IOSR-JRME, 7( 1 ).

Mukminan. (2015). Kurikulum Masa Depan. Banten, Indonesia.: Universitas Sultan Ageng Tirtayasa.

Nyova Fazriani, D. A. (2019). Pengaruh Pendekatan HOTS Terhadap Keterampilan Membaca Peserta Didik. Jurnal Stilistika, 12 ( 2). 
Okayana, K. (2019). The Development of Higher Order Thinking Skills-Based Assessment Instrument for Elementary School Integrated Thematic Learning. Journal of Education and Practice, 10 (15). doi:10.7176/JEP

Purwanto, A. d. (2020). EM-SETS: An Integrated e-module of Environmental Education and Technology in Natural Science Learning, (2020), pp. 7014 - 7025. International Journal of Advanced Science and Technology, 29(03).

Ridwan. (2019). Pembelajaran Berbasis HOTS. Tangerang: Tira Smart.

Ridwan, A. S. (2019). Pembelajaran Berbasis HOTS. Tangerang: Tira Smart.

Rofiah, E. (2013). Penyusunan Instrumen Tes Kemampuan Berpikir Tingkat Tinggi Fisika Pada Siswa SMP. Jurnal Pendidikan Fisika, 1.

Sani, A. (2016). Penialaian Autentik. Jakarta: Bumi Aksara.

Setyawan, R. (2020). Designing Assesment Task of Student Creative Thinking Assisted by Google Form. International Journal of Innovative Science and Research Technology, Vol 5.

Subadar. (2017). Penguatan Pendidikan Karakter (PPK) Berbasis Higher Order Thinking Skill (HOTS). Jurnal Pedagogik, 4(1).

Sugiyono. (2013). Metode Penelitian Pendidikan (Pendekatan Kuantitatif, Kualitatif dan R\&D). Bandung: Alfabeta.

Sutanto, P. ( 2019). Modul Penyusunan Soal Keterampilan Berpikir Tingkat Tinggi (HOTS). Jakarta: Direktorat Pembinaan Sekolah Menengah Atas.

Sutanto, P. (2019). Modul Penyusunan Soal Keterampilan Berpikir Tingkat Tinggi (HOTS). Jakarta: Direktorat Pembinaan Sekolah Menengah Atas.

Wayan, W. (2017). Modul Penyusunan Soal Higher Order Thinking Skill (HOTS). Jakarta: Direktorat Pembinaan SMA.

Witri, G. H. (2014). Analisis Kemampuan Siswa Sekolah Dasar dalam Menyelesaikan SoalSoal Matematika Model The Trends for International Mathematics and Sciencedi Pekan baru. Jurnal Primary Program Studi Pendidikan Guru Sekolah Dasar Fakultas Keguruan dan IImu Pendidikan Universitas Riau, 3 ( 1). 